\title{
EXPERIMENTAL TREATMENT OF AUSTRALIAN TRACHOMA*

\author{
WITH SPECIAL REFERENCE TO LEDERKYN
}

\author{
BY \\ IDA MANN \\ Perth, Western Australia
}

IT is now approximately 5 years since, following the initial ophthalmic survey of the State of Western Australia, it became apparent that a mass campaign for the eradication of trachoma would have to be undertaken by the Public Health Department.

\section{Review of Various Trial Treatments}

Various pilot projects were initiated to ascertain whether Australian trachoma behaved in the same way towards the various available therapeutic measures as that in other countries and to enable us to work out a method of mass treatment suitable for routine use in the somewhat peculiar conditions met with in the remoter parts of the State where trachoma was rife.

In the earlier pilot projects sulphadiazine, trisulpha, and sulphadimidine were used orally alone, or combined with local aureomycin or terramycin ophthalmic ointment. A few cases were treated with ointment alone. Some cases were treated by expression of the follicles before the drug treatment was begun. Clinical trials of the sulphones (D.A.D.P.S.) were also made following the observation that active trachoma was unknown in patients undergoing treatment for leprosy. At the present time trial treatment (with repeated observations) and mass treatment (blanket treatment in areas of high incidence) with sulpha-methoxypyridazine (Lederkyn) is in progress. This communication deals mainly with the results of this trial treatment.

Our earlier results with the various treatments mentioned above coincided largely with those of observers in other parts of the world, and the impression gained was that treatment with any of the soluble sulphas by mouth for 14 days combined with local treatment of the eyes with aureomycin or terramycin ointment for 6 weeks gave excellent results. Treatment with oral sulpha alone was also very effective. A few cases treated with local ointment alone responded, though somewhat more slowly. D.A.D.P.S. was also effective, but acted much more slowly, and was accompanied by various toxic manifestations which rendered its use unjustifiable. Expression of the follicles was usually followed by worse scarring than drug treatment alone and was soon abandoned. 
Local conditions in Australia preclude the general use of combined oral and local treatment. The patients are almost all aboriginals or half-castes of various degrees. The incidence of trachoma among the coloured population is $50-80$ per cent. according to locality. (That in the white population is 3-6 per cent. but is rising.) The native patients are nomadic, philosophic, and uncooperative. They cannot be relied on to remain in one place for anything like 6 weeks, nor can they be persuaded in most cases to attend voluntarily even once a day regularly for 2 weeks. They consider physical disease as something to be borne with stoicism and they fail to see the connexion between the early stages of trachoma and the blindness of the old people. They think that treatment is unnecessary and will evade it if possible. Their lack of co-operation will often extend to receiving a tablet in the mouth from the nurse and retaining it in the cheek while the prescribed glass of water is drunk, only to spit it out later in the clinic garden:

Inserting ointment in the eyes three times or even twice a day is an impossibility in most cases.

We are therefore committed to finding the simplest, shortest and most effective method of oral treatment for use among native school children over whose movements we have at least some control.

\section{Natural History of Trachoma in Australia}

The natural history of trachoma in Western Australia appears to imply that if we could ensure that no child reached school-leaving age with active trachoma, its incidence in the next generation would be enormously reduced. Infection usually occurs before the age of 2 years. The onset is insidious, the symptoms practically nil. The type of disease is trachome pur in most instances, though secondary infection can occur. If this does occur, the mother may be more co-operative, as the eyes look inflamed. There is no medical supervision for native pre-school children, and it must be remembered that the native population lives mostly in scattered groups often 20 to 50 miles apart, without transport or access to hospital except for severe emergencies when contact may have to be made by aeroplane. The only method of reaching a high percentage of pre-school children is by instituting blanket treatment without preliminary diagnosis and delegating it to white persons who are able to contact groups of natives (e.g. Health Inspectors, Station Managers, and Missionaries) and are willing to treat them.

When the child reaches school age (and sometimes before) there is at present a good chance of his attending school, at least sporadically, for some years. In the metropolitan area and the City of Perth and in other large towns, practically all native children attend school. In the remoter districts they are catered for by missions with a State School teacher attached, by orphanages, by convent schools, and by small classes held on cattle and sheep stations for the children of employees. 
A child leaving school without ever having caught trachoma or one cured during the school years and remaining cured until 14 or so, very seldom contracts trachoma later in life. This is possibly due to the inculcation of habits of personal hygiene at school and not to any acquired or natural immunity.

\section{Treatment of School Children}

We have therefore concentrated our efforts on treatment of school-age children. For this, some form of oral sulpha which does not have to be administered frequently or for a long time is desirable. We have the complete co-operation of the teaching profession, who supervise the taking of the sulpha and make sure each tablet is swallowed and that sufficient water is drunk. They also report any adverse symptoms which may arise. Allergic or other reactions to the sulpha group seem to be rare in Australian aboriginals, very few cases having been encountered among many thousand treatments given and none of them serious. School treatment is given as a blanket treatment of every native or part-native child whether infected or not once a year, in March, after the long summer holiday. It must be repeated each year as the proportion of re-infections is high in the younger children after the holiday. The children return to the filthy life of the camps and come into close contact with the untreated pre-school children and return to school with active trachoma again.

This happens less and less often, however, as they grow older and children of 12 years old or so seldom become re-infected.

The question of re-infection versus relapse after sulpha treatment cannot be settled in Western Australia as contact with untreated cases cannot be avoided.

\section{Diagnostic Criteria}

Since the concept of trachome pur as a symptomless condition in children is possibly a new one in countries not previously involved in trachoma eradication programmes, it may be as well to quote from the recommendations of the Expert Committee on Trachoma (of World Health Organisation) which met at Geneva in 1956. It is there stated that the diagnostic criteria of trachoma must be the presence of any two of the following signs :

(1) Follicles (conjunctival or limbal);

(2) Epithelial keratitis most marked in the upper part of the cornea;

(3) Pannus in the upper part of the cornea;

(4) Typical scars.

This has been adhered to by the School Medical Officers and other trachoma workers in Western Australia and in all other Australian Surveys. 
It seems probable that the trachoma incidence in Western Australia appears unduly large in comparison with that in the rest of this continent because all Western Australian School Medical Officers are trained in its recognition and evert all lids as a routine in all school medical inspections.

\section{Course of Trachome Pur}

At its inception in infants usually nearly a year old, the disease is very mild and consists of the appearance of scattered necrotic follicles on the tarsal plate and in the fornix. There is no discharge. The eye is not red and the lid not obviously swollen. There is slight epithelial infiltration of the upper margin of the cornea, but pannus is slow in appearing and is not usually obvious with a loupe until between the ages of 2 and 3 years, when it appears as an "open limbus" or merely as slight irregularity. In untreated cases without secondary infection the vessels gradually extend to about $2 \mathrm{~mm}$. by age 4 . In a few severe cases, usually with secondary infection, the vessels extend to the pupil area, but this is rare before age 7 or 8 , and is then not common. Limbal follicles and the resultant pits are common and are usually only accompanied by very short pannus vessels. Scarring of the tarsal plate appears slowly, but can be marked by age 7; it is worse in cases with secondary infection. In untreated trachome pur, healing usually occurs in the 20 s with fine scarring, limbal pits, and empty vessels visible for about $3 \mathrm{~mm}$. Our original survey (1953) showed that roughly 10 per cent. of trachoma cases become "blind" in later life and an additional 7 per cent. have definitely impaired sight. Among these, secondary infection is the rule.

\section{Results of Treatment}

That the plan of treating school children, even though it has not yet become absolutely routine and universal, is already having an effect on the incidence of the active trachoma in the general population, is shown in the Figure (overleaf), in which the percentage of cases with active infectious trachoma (with follicles) of the total cases of trachoma seen is plotted against age.

Two surveys are shown: in 1953 before any treatment had been given and in 1956 after the use of oral sulphadiazine.

It will be seen that the effect of the treatment has been to push back the age at which the trachoma is active to the younger age groups. For example, in 1953, 95 per cent. of all trachoma in children of 10 was active, whilst in 1956 only 60 per cent. was active.

These results were achieved with somewhat irregular treatment during $2 \frac{1}{2}$ years. Later, more schools and stations entered the scheme and sulphadimidine was used instead of sulphadiazine; at the present time practically all the schools are willing to do an annual blanket treatment and to treat all new entrants on arrival. This last is essential, as if it is neglected the new 


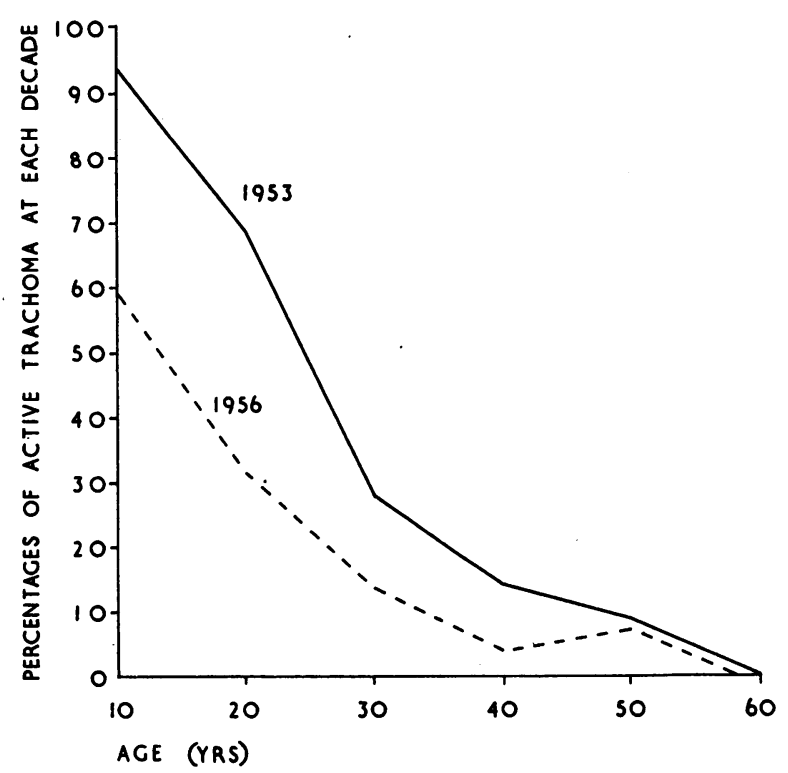

FIGURE.-Percentages of active trachoma at each decade.

arrivals may easily infect the cured children before the annual blanket treatment is due again. It is to be regretted that shortage of Public Health Staff makes it utterly impossible to inspect every school and station every year.

Introduction of Lederkyn (Midicel).-As soon as it was realized that Lederkyn was a slow-acting relatively non-toxic sulpha which only had to be given once a day, we decided to start clinical trials. From reports received it was also apparent that a triple dose could be given on Fridays to last over the weekend. This was a great advantage as the teachers could not guarantee that the weekend treatment with sulphadimidine would be carried out though the child was given the tablets to take home on the Fridays.

Also the necessity for calculating the dose on the weight of the child introduced a difficulty as did the necessity for two doses a day. These had perforce to be given at 9 a.m. and at 3.30 p.m. so that even spacing in the 24 hrs was impossible.

The introduction of Lederkyn obviated all these troubles. As the dose is based on age, not weight, and as all school children are aged 6 or over, a single tablet a day (with three on Fridays) is all that is required. It was therefore decided to use Lederkyn for blanket treatment in certain areas and in others to make detailed observations on its action in schools which were easily accessible. This report deals with those cases which it was possible 
to observe at intervals over 2 to 10 months. The children were not segregated and many went to camps for holidays after the treatment was finished. In all cases the dose for children aged 6 and over, was one tablet a day, for those aged 2 to 6 half a tablet a day, and for infants a quarter tablet a day. Most of those treated, however, were of school age.

The effect of treatment with Lederkyn was especially investigated in 105 cases with the natural history and clinical appearances described above constantly in mind. The results described below appeared to justify an extension from the "pilot project" to a limited "mass campaign" as advised by the World Health Organization. At the present time an attempt has been made to give a 2 weeks' course of Lederkyn to every native and partnative person in the Kimberley District who is under 20 years of age, irrespective of whether trachoma has ever been either looked for or diagnosed. Four months after the treatment a follow-up survey is planned to be carried out to assess the result, and the mass campaign will then be applied to the rest of the State if it appears justified.

Clinical Results.- In the 102 children treated in the trial of Lederkyn and in previous observations with the other soluble sulphas, the following sequence of events occurs.

At the end of the 2 weeks treatment there is very little change except that the hyperaemia is less and any discharge which may have been present (from secondary infection) has cleared up. The follicles appear unchanged. The drug has killed the virus but the ordinary processes of repair must still come into play to remove the necrotic debris and to convert the follicle into a minute stellate scar. In some cases, treated very early, it may eventually become impossible to detect any scarring even with the slit lamp. A complete restoration to normal may occur and, if there is no scarring and the corneal change has been an epithelial oedema and infiltration only, it will not be possible to say that the child has ever had trachoma.

A month after beginning the treatment the tarsal plate is becoming smoother, each follicle being still visible but flat. This appearance of flattening of the follicles is characteristic of treated trachoma, and is a sign that cure will result. In white children, trachoma and folliculosis may co-exist and one can watch the flattening of the pale slightly-yellow trachoma follicles after treatment, while the others, pink and solid-looking, remain untouched. It might almost be said that, where diagnosis of a follicular condition is uncertain, the behaviour of the follicles 6 weeks after treatment with sulpha, affords considerable help. I have not found folliculosis or spring catarrh or any other of the non-trachomatous folliculoses to be influenced in any way by sulpha. Trachoma in white children often co-exists with other conditions, but, in my experience, native children do not often suffer from folliculosis or spring catarrh. 
This flattening and recession of the follicles continues slowly, some taking 9 months before they are converted into scars. It is therefore of little use to assess the value of a treatment too soon, say after 6 weeks.

The corneal changes retrogress more quickly. During their development oedema of the epithelium at the upper limbus precedes infiltration with leucocytes, and this in turn precedes the "opening" of the limbus and the appearance of the first "down-sprouts" of the pannus. Oedema is always in advance of vascularization in cases which are deteriorating. After treatment retrogression occurs in the reverse order. Oedema disappears before vascularization, often within 3 weeks. Gradually the vessels come to be clear and then after months they empty and become mere slender endothelial tubes. These remain visible for years, possibly permanently, and can always be made to fill with blood by manipulating the lids and by exposure during slit-lamp examination.

Limbal follicles become converted into Herbert's pits during the first 2 or 3 months after treatment. These are permanent and provide throughout life an absolutely certain diagnostic and pathognomonic sign of past trachoma. They may sometimes be seen in the almost entire absence of scarring and corneal vascularization in adults who have no knowledge of ever having had trachoma.

In other words, treatment of trachome pur with sulpha accelerates the natural process of cure by removing the virus. Left to itself trachome pur resolves, usually in the early twenties and in some cases it may be symptomless throughout. It must however be eradicated from the population as it forms the reservoir from which come the severe secondarily-infected cases, which we look on as "Egyptian" trachoma and which has such serious results.

Treatment of the most severe cases with sulpha may yield surprisingly good results even when the pannus has covered the pupillary area. The clearing up of the secondary infection and the removal of the epithelial infiltrates and oedema may lead to remarkable improvement in sight. I have seen several cases "too blind to perform work for which eyesight is essential" restored to $6 / 9$ in the better eye within 9 months.

Entropion and trichiasis do not occur in school children. These symptoms may become troublesome in the late thirties but may also be found by age 25. A plastic operation should of course be combined with sulpha treatment and if possible with local treatment with antibiotic ointment.

\section{Lederkyn Trials}

(A) White Children.-Table I (opposite) shows in detail the results in nineteen white children, and brings out certain points. Most of these children were living in an orphanage or had been born in Italy or elsewhere in Europe. 
TABLE I

RESULTS IN 19 WHITE CHILDREN

\begin{tabular}{|c|c|c|c|c|c|}
\hline $\begin{array}{l}\text { Case } \\
\text { No. }\end{array}$ & $\begin{array}{c}\text { Age } \\
\text { (yrs) }\end{array}$ & History & Stage of Trachoma & $\begin{array}{c}\text { Time of } \\
\text { Observa- } \\
\text { tion } \\
\text { (mths) }\end{array}$ & Result \\
\hline 1 & $9 / 12$ & $\begin{array}{l}\text { Born in Perth } \\
\text { of Italian par- } \\
\text { ents from Sicily }\end{array}$ & $\begin{array}{l}\text { Hyperaemia } \\
\text { Papillary hypertrophy } \\
\text { One or two follicles }\end{array}$ & $2 \frac{3}{4}$ & $\begin{array}{l}\text { Cured } \\
\text { No trace of disease }\end{array}$ \\
\hline 2 & 5 & $\begin{array}{l}\text { Born in Sicily. } \\
\text { Had an inter- } \\
\text { rupted treat- } \\
\text { ment a year } \\
\text { before }\end{array}$ & $\begin{array}{l}\text { Pale follicles and pink fol- } \\
\text { licles } \\
\text { Pus in tonsils }\end{array}$ & $2 \frac{1}{4}$ & $\begin{array}{l}\text { Cured } \\
\text { Pale follicles have gone } \\
\text { Some folliculosis remains }\end{array}$ \\
\hline 3 & 7 & $\begin{array}{l}\text { Sister of Cases } \\
1 \text { and } 2 \text {, born } \\
\text { in Sicily. Had } \\
\text { insufficient } \\
\text { treatment a } \\
\text { year before }\end{array}$ & $\begin{array}{l}\text { Tarsal and limbal follicles } \\
\text { Typical and moderately } \\
\text { severe }\end{array}$ & $2 \frac{1}{4}$ & $\begin{array}{l}\text { Cured } \\
\text { No follicles } \\
\text { Some irregularity of limbus }\end{array}$ \\
\hline 4 & 7 & Greek & $\begin{array}{l}\text { Pale tarsal follicles } \\
\text { Limbal infiltrates } \\
\text { Folliculosis in lower fornix }\end{array}$ & $2 \frac{1}{4}$ & $\begin{array}{l}\text { Cured } \\
\text { No tarsal follicles } \\
\text { Limbus normal } \\
\text { Folliculosis present }\end{array}$ \\
\hline 5 & 9 & $\begin{array}{l}\text { Australian } \\
\text { born; infected } \\
\text { in an orphan- } \\
\text { age at } 8\end{array}$ & $\begin{array}{l}\text { Many follicles on tarsus } \\
\text { Limbus faintly oedematous }\end{array}$ & 5 & $\begin{array}{l}\text { Cured } \\
\text { Follicles flattening at } 1 \\
\text { mth, almost gone at } 4 \\
\text { mths, just visible at } 5 \\
\text { mths }\end{array}$ \\
\hline 6 & 9 & $\begin{array}{l}\text { Infected in } \\
\text { same orphan- } \\
\text { age as Case } 5\end{array}$ & $\begin{array}{l}\text { Follicles }++ \\
\text { Limbus open and irregular }\end{array}$ & 5 & $\begin{array}{l}\text { Cured } \\
\text { Infiltrates gone at } 1 \mathrm{mth} \\
\text { Vessels empty at } 4 \mathrm{mths} \\
\text { No trace of trachoma at } \\
5 \mathrm{mths}\end{array}$ \\
\hline 7 & 11 & $\begin{array}{l}\text { Infected in } \\
\text { orphanage }\end{array}$ & $\begin{array}{l}\text { Follicles }++ \\
\text { Early pannus }\end{array}$ & 4 & $\begin{array}{l}\text { Probably cured } \\
\text { Follicles flattening at } 3 \text { wks } \\
\text { Vessels emptying at } 2 \mathrm{mths} \\
\text { Vessels empty at } 4 \text { mths } \\
\text { Remains of follicles stil } \\
\text { visible }\end{array}$ \\
\hline 8 & 11 & $\begin{array}{l}\text { Infected in } \\
\text { orphanage pro- } \\
\text { bably }\end{array}$ & $\begin{array}{l}\text { Follicles }++ \\
\text { Early pannus } \\
\text { Limbal follicles }\end{array}$ & 5 & $\begin{array}{l}\text { Probably cured } \\
\text { Vessels quietening at } 1 \mathrm{mth} \\
\text { and infiltrates gone } \\
\text { Herbert's pits at } 2 \mathrm{mths} \\
\text { Follicles flat but still visible } \\
\text { at } 5 \mathrm{mths}\end{array}$ \\
\hline 9 & 12 & Orphanage & Few follicles, some limbal & 5 & $\begin{array}{l}\text { Cured } \\
\text { Herbert's pits at } 2 \text { mths } \\
\text { Lids practically normal a } \\
5 \cdot \mathrm{mths}\end{array}$ \\
\hline
\end{tabular}

continued 
TABLE I-continued

\begin{tabular}{|c|c|c|c|c|c|}
\hline $\begin{array}{l}\text { Case } \\
\text { No. }\end{array}$ & $\begin{array}{c}\text { Age } \\
(\mathrm{yrs})\end{array}$ & History & Stage of Trachoma & $\begin{array}{c}\text { Time of } \\
\text { Observa- } \\
\text { tion } \\
\text { (mths) }\end{array}$ & Result \\
\hline 10 & 12 & Orphanage & $\begin{array}{l}\text { Very few follicles when first } \\
\text { seen, a few on limbus }\end{array}$ & 5 & $\begin{array}{l}\text { Cured } \\
\text { Slight limbal irregularity } \\
\text { and flat follicles at } 2 \text { mths. } \\
\text { Vessels empty } \\
\text { Lids normal at } 5 \mathrm{mths}\end{array}$ \\
\hline 11 & 12 & Orphanage & $\begin{array}{l}\text { Florid trachoma } \\
\text { Faint limbal involvement }\end{array}$ & 5 & $\begin{array}{l}\text { Much improved quickly } \\
\text { Healed at } 5 \text { mths showing } \\
\text { scarring }\end{array}$ \\
\hline 12 & 12 & Orphanage & $\begin{array}{l}\text { Follicles and oedema only } \\
\text { One irregular vessel }\end{array}$ & 5 & $\begin{array}{l}\text { Cured } \\
\text { Trachoma disappeared } \\
\text { Some folliculosis remained }\end{array}$ \\
\hline 13 & 12 & $\begin{array}{l}\text { Lithuanian } \\
\text { born in Ger- } \\
\text { many }\end{array}$ & $\begin{array}{l}\text { Papillary hypertrophy and } \\
\text { opaque follicles } \\
\text { Limbus not involved }\end{array}$ & 3 & $\begin{array}{l}\text { Cured } \\
\text { All opaque follicles and } \\
\text { papillary hypertrophy dis- } \\
\text { appeared at } 3 \text { mths } \\
\text { Some folliculosis remained }\end{array}$ \\
\hline 14 & 12 & Orphanage & $\begin{array}{l}\text { Treated for blepharitis and } \\
\text { folliculosis } 9 \text { mths before } \\
\text { Early trachoma supervened } \\
\text { Open limbus }\end{array}$ & 5 & $\begin{array}{l}\text { Cured } \\
\text { Limbus normal in } 1 \mathrm{mth} \\
\text { Trachoma follicles at } 5 \\
\text { mths disappeared } \\
\text { Some folliculosis remained }\end{array}$ \\
\hline 15 & 13 & Orphanage & $\begin{array}{l}\text { Blepharitis and follicular } \\
\text { condition of naso-pharynx } \\
\text { Florid trachoma when first } \\
\text { seen } \\
\text { Subsiding when Lederkyn } \\
\text { started } \\
\text { Had had sulphadimidine } \\
\text { and terramycin ointment } 7 \\
\text { mths before }\end{array}$ & 5 & $\begin{array}{l}\text { Cured } \\
\text { Trachoma follicles disap- } \\
\text { peated but blepharitis recur- } \\
\text { red and follicles remained in } \\
\text { naso-pharynx and lower for- } \\
\text { nix }\end{array}$ \\
\hline 16 & 14 & Orphanage & $\begin{array}{l}\text { Slight trachoma } \\
\text { Open limbus and down } \\
\text { sprouts }\end{array}$ & 5 & $\begin{array}{l}\text { Cured } \\
\text { Remains of vessels visible }\end{array}$ \\
\hline 17 & 14 & $\begin{array}{l}\text { Diagnosed in } \\
\text { school inspec- } \\
\text { tion } 4 \text { years } \\
\text { before }\end{array}$ & $\begin{array}{l}\text { Many follicles on tarsal } \\
\text { plate but not necrotic } \\
\text { Papillary hypertrophy } \\
\text { Limbus absolutely normal } \\
\text { Almost certainly not tra- } \\
\text { choma; may be A.P.C. } \\
\text { virus, chronic? }\end{array}$ & 2 & $\begin{array}{l}\text { Follicles diminished in num- } \\
\text { ber without flattening } \\
\text { Limbus remained normal } \\
\text { This had never been a case } \\
\text { of trachoma }\end{array}$ \\
\hline 18 & 14 & Maltese & $\begin{array}{l}\text { Early trachoma } \\
\text { Open limbus and down } \\
\text { sprouts }\end{array}$ & 5 & $\begin{array}{l}\text { Nearly normal at } 2 \mathrm{mths} \\
\text { Cured at } 5 \mathrm{mths}\end{array}$ \\
\hline 19 & 15 & Orphanage & $\begin{array}{l}\text { Slight secondary infection } \\
\text { Follicles } \\
\text { Irregular limbus } \\
\text { Hyperaemia }\end{array}$ & 5 & $\begin{array}{l}\text { Still slightly hyperaemic and } \\
\text { remains of follicles seen at } \\
5 \text { mths }\end{array}$ \\
\hline
\end{tabular}


(i) In many cases it seemed likely that the disease had been present before their arrival in Australia. In the orphans, it could have been introduced by one child and spread within the institution. Cases 5, 6, 12, and 14 are known to have been uninfected the year before.

(ii) The progress made during the period of observation demonstrates that the younger the child the quicker the cure and the greater the chance of complete restoration to normal. It also shows that all children are likely to be cured, though even after 5 months the follicles are not fully resorbed in some cases. No new raised follicles appeared during the period of observation. The children were seen at intervals of 3 weeks to a month.

(iii) Case 17 is included mainly to show that cases showing pink or translucent follicles on the tarsal plate with no limbal involvement after 4 years are not to be diagnosed as trachoma and will not be benefited by sulpha.

(iv) In several cases treatment had been given before. Various sulphas had been used, but we had very little proof that the dosage had been thorough. We know from experience with other sulphas that irregular or intermittent treatment is seldom successful. Cases are often labelled "resistant" when the patient has failed to take the weekend doses or has taken only an occasional tablet. In the Lederkyn trials we knew exactly what had been given. Cases 8, 9, 10,11, 14, 15, 16, and 19 had had some treatment, and Cases 2 and 3 may have done so.

Dosage.-We tried various doses. Cases 13 and 17 received a small dose, one-quarter tablet a day for 14 days. Case 13 did as well as the rest, but Case 17 did not have trachoma.

Cases 4, 5, 6, and 7 were given two tablets a day for 1 week. They did reasonably well, though Case 7 was not completely free of flat follicles. Cases $6,8,9,10,12,14,15$, and 19 received only twelve doses instead of fourteen, but this did not appear to matter. The rest had fourteen doses, one a day.

Cure.-The criteria of cure are difficult to define. We took the lack of appearance of fresh follicles during the period of observation, together with disappearance of hyperaemia, papillary hypertrophy and limbal infiltrates, to mean cure, if in addition the follicles were all flat and disappearing or had all disappeared. The conversion of limbal follicles into Herbert's pits is also a helpful sign of improvement.

(B) Coloured and Full-Blood Aboriginal Children.-The rest of the 102 children involved in the Lederkyn clinical trials were full-blood or half-caste 
aboriginals. In such children the diagnosis is seldom complicated by folliculosis or vernal catarrh, but on the other hand they are constantly exposed to re-infection outside the school or mission where they are being treated (Table II).

(1) Native Settlement in the Suburbs of Perth (Allawah Grove).-The treatment was given every morning by a Department of Public Health Officer and it is certain that it was administered. There was little co-operation from the natives, however, and the follow-up observations were very unsatisfactory. Many of the patients went away, and other untreated natives came to the camp and re-infected some already seen to be cured. Yet even under these poor conditions the treatment appeared to have a good effect.

Nineteen children were treated, ranging in age from 18 months to 11 years. Two of them had probably been treated before, one possibly. The rest were new cases. Table II shows that, of these nineteen children treated under very poor conditions, the majority appear at the moment to be cured, but six showed signs of re-infection after having been seen to be completely quiet previously. The re-infections were all in children under age 6. This looks hopeful for the possibility of eradication during school life.

TABLE II

RESULTS IN 19 NON-WHITE CHILDREN

\begin{tabular}{c|c|l|c|l}
\hline $\begin{array}{c}\text { Case } \\
\text { No. }\end{array}$ & $\begin{array}{c}\text { Age } \\
\text { (yrs) }\end{array}$ & \multicolumn{1}{|c|}{ Stage of Trachoma } & $\begin{array}{c}\text { Time of } \\
\text { Observa- } \\
\text { tion (mths) }\end{array}$ & \multicolumn{1}{|c}{ Result } \\
\hline 1 & $1 \frac{1}{2}$ & Early & 8 & Healed without trace \\
\hline 2 & 2 & Early secondary infection & 10 & $\begin{array}{l}\text { Almost healed at 2 mths } \\
\text { Vessels emptying at 8 mths } \\
\text { Just detectable remains of fol- } \\
\text { licles at 10 mths }\end{array}$ \\
\hline 3 & 2 & Trachoma & 10 & $\begin{array}{l}\text { Nearly well at 8 mths } \\
\text { At 10 mths papillary hypertrophy } \\
\text { and a few deep follicles infected } \\
\text { Had been in a highly infect } \\
\text { area after treatment }\end{array}$ \\
\hline 4 & 2 & Many follicles & 10 & $\begin{array}{l}\text { Cured without trace at 8 mths } \\
\text { Re-infected with secondary in- } \\
\text { fection at 10 mths }\end{array}$ \\
\hline 5 & $2 \frac{1}{2}$ & Slight & 10 & $\begin{array}{l}\text { Cured without trace at 8 mths } \\
\text { Re-infected at 10 mths }\end{array}$ \\
\hline 6 & 3 & Slight & 10 & $\begin{array}{l}\text { Almost cured at 2 mths } \\
\text { Re-infected at 10 mths }\end{array}$ \\
\hline 7 & 4 & $\begin{array}{l}\text { Follicles } \\
\text { Secondary infection }\end{array}$ & 10 & $\begin{array}{l}\text { Follicles and discharge gone at } \\
\text { 2mths } \\
\text { Cured till 8 mths } \\
\text { At 10 mths some deep follicles, } \\
\text { ?re-infection }\end{array}$ \\
\hline
\end{tabular}


TABLE II-continued

\begin{tabular}{|c|c|c|c|c|}
\hline $\begin{array}{l}\text { Case } \\
\text { No. }\end{array}$ & $\begin{array}{l}\text { Age } \\
\text { (yrs) }\end{array}$ & State of Trachoma & $\begin{array}{l}\text { Time of } \\
\text { Observa- } \\
\text { tion (mths) }\end{array}$ & Result \\
\hline 8 & 4 & Slight & 10 & $\begin{array}{l}\text { Appeared cured from } 2 \text { nd to } 8 \text { th } \\
\text { mth } \\
\text { At 10th month active again, } \\
\text { ? re-infection }\end{array}$ \\
\hline 9 & 5 & Slight & 10 & $\begin{array}{l}\text { Appeared normal at } 2 \mathrm{mths} \\
\text { Still cured at } 10 \mathrm{mths}\end{array}$ \\
\hline 10 & 7 & Moderate & 10 & $\begin{array}{l}\text { Scars appeared at } 2 \text { mths } \\
\text { At } 8 \text { mths much scarring and } \\
\text { secondary infection } \\
\text { At } 10 \text { mths quiet with scars and } \\
\text { pits only }\end{array}$ \\
\hline 11 & 7 & $\begin{array}{l}\text { Follicles and scars. Treated } \\
\text { once before with sulphadiazine }\end{array}$ & 15 & $\begin{array}{l}\text { Improving at } 2 \mathrm{mths} \\
\text { Slight roughness only at } 8 \mathrm{mths} \\
\text { Quiet and scarred at } 10 \mathrm{mths} \\
\text { Scars and pits only at } 15 \mathrm{mths}\end{array}$ \\
\hline 12 & 8 & Moderate & 10 & $\begin{array}{l}\text { Much improved at } 2 \mathrm{mths} \\
\text { Scars, pits, and vessels at } 8 \mathrm{mths} \\
\text { Remained quiet } 10 \mathrm{mths}\end{array}$ \\
\hline 13 & 8 & Moderate & 10 & $\begin{array}{l}\text { Scars appearing at } 2 \mathrm{mths} \\
\text { Remained quiet at } 10 \mathrm{mths}\end{array}$ \\
\hline 14 & 8 & Moderate & 2 & Follicles disappeared \\
\hline 15 & 8 & Moderate & 10 & Follicles disappeared \\
\hline 16 & 9 & Moderate & 10 & $\begin{array}{l}\text { Follicles gone at } 2 \mathrm{mths} \\
\text { Scars and pits at } 10 \mathrm{mths}\end{array}$ \\
\hline 17 & 9 & $\begin{array}{l}\text { Follicles and scars-had had } \\
\text { treatment with sulphadiazine }\end{array}$ & 10 & $\begin{array}{l}\text { Follicles still seen at } 2 \mathrm{mths} \\
\text { Slightly rough at } 8 \mathrm{mths} \\
\text { Scars, pits, and empty vessels at } \\
.10 \mathrm{mths}\end{array}$ \\
\hline 18 & $10^{\circ}$ & Follicles & 10 & $\begin{array}{l}\text { Scars appearing at } 2 \text { mths } \\
\text { A few scars and pits only at } \\
8 \mathrm{mths} \\
\text { Remained cured at } 10 \mathrm{mths}\end{array}$ \\
\hline 19 & 11 & Follicles & 10 & $\begin{array}{l}\text { Pale, scarred, no hyperaemia by } \\
8 \text { mths } \\
\text { Many pits, remaining quiet } \\
10 \text { mths }\end{array}$ \\
\hline
\end{tabular}

(2) Pinjarra-Serpentine Area.-These were children living in a more permanent shanty camp than Allawah Grove. There was good co-operation in this camp as thorough treatment with sulphadiazine had been carried out there 3 years earlier and the people had understood its purpose. These natives were clean, and the previous treatment had had good results. The Lederkyn treatment was administered by the Health Inspector each morning. 
Seventeen children were treated, but it was only possible to watch them for 7 weeks. In one case there was complete healing in this time and in fourteen the follicles were flat, the hyperaemia had disappeared, and the prognosis looked good. Two cases had severe impetigo and secondary infection when first seen; the impetigo and secondary infection cleared up but a few active follicles were still present at 7 weeks. Two of the seventeen were known to have had previous treatment, probably with sulphadiazine, but had relapsed or become re-infected.

(3) New Norcia Convent School for Native and Coloured Children.-Here the children are under control, the treatment is efficiently given, and the results good. Various treatments have been tried here in the past and all have proved good, but there is a very high rate of re-infection as the children go away for long holidays and to visit relations, etc. An annual blanket treatment is given in February each year to each child. The trachoma in this area is severe and there is often secondary infection.

Of 47 children investigated, 27 had been treated with other sulphas before. Eleven of these had been seen cured in the past and had become re-infected. Of this 27, two were cured after 2 months and fourteen at the end of the third month. Ten of the rest showed the remains of flattening follicles at 3 months and should now be well. One was cured but apparently re-infected at the end of 3 months. All had scars and pits and emptying vessels.

The other twenty children had no record of previous treatment. Of these, thirteen showed no trace of follicles at the end of the third month, and the rest had remains of follicles only. Three showed complete restoration to normal with no scars or corneal vessels, and the rest showed scars, pits, and empty vessels.

\section{Conclusions}

It is not possible to assess these results in percentages of cures since some cases were not followed-up long enough and others ran the risk of reinfection. We can say, however, that in every case observed the same sequence of events took place within the first 3 months: flattening of the follicles, disappearance of hyperaemia and of papillary hypertrophy, and cessation of discharge if this had been present.

That Lederkyn acts by killing the virus is shown by the number of patients observed who had no secondary infection. The general impression is that the response to Lederkyn is quicker and better than that to the other sulpha drugs we have tried, and even apart from this, the ease of its administration makes it at the moment the treatment of choice.

It is proposed therefore to use Lederkyn in the annual treatment in schools and stations in Western Australia for the present. 